4. Vitchenko, A. (2014). Regularity of training of military educators: from competence to professionalism and excellence: Book of abstracts. Kyiv, № 1 (29). p. 50

5. Kuzmina, N. (1982). Methods of systemic pedagogical research

6. Maslov, V. (2013). Actual factors of development of military education. Military education. №1. p.139-148 Retrived from: http://nbuv.gov.ua/ UJRN/vios_2013_1_18.

7. Matsevko, T. (2007). Psychological features of development of managerial competence of future masters of military profile, Dissertation, PhD (Psychological sciences). Kyiv., p. 225.

V. Blyzniuk, Head of Department of Vehicle Training

Taras Shevchenko National University of Kyiv, Kyiv, Ukraine

bvv_2010@ukr.net

ORCID ID 0000-0001-5187-032X

\title{
PSYCHOLOGICAL AND PEDAGOGICAL FEATURES OF THE PROCESS OF PROFESSIONAL TRAINING OF FUTURE OFFICERS OF LAW ENFORCEMENT ACTIVITIES OF THE ARMED FORCES OF UKRAINE IN THE CONDITIONS OF UNDERGRADUATE
}

The article substantiates the psychological and pedagogical features of the process of professional training of future law enforcement officers of the Armed Forces of Ukraine in a bachelor's degree. It is established that the professional training of future law enforcement officers is gradually moving to the readiness of the future officer to perform professional tasks. It is specified that the educational process in military institutions of higher education takes place in conditions of contradictions between new constantly growing requirements to the modern level of training of future officers and insufficient traditional level of training, between creative level of teaching and reproductive character of training which can be solved by introduction of new innovative technologies. and teaching methods. It has been determined that the process of formation of knowledge, skills and professional skills of future law enforcement officers should be based on two main stages: problem-subject, during which there is a primary perception and understanding of the content and experience of further professional activity; value-regulatory, according to which the formation of team skills and professional skills of the future officer, the development of creative style, the formation of motives, values, leadership qualities, etc. Psychological components that affect the training of future officers are identified: motivation to learn, emotional and volitional personality traits of the future officer, intellectual readiness to solve professional tasks, formed skills and abilities to perform professional tasks, a set of personal and professional qualities of the future officer, reflex. It is determined that the level of professional training of future law enforcement officers is determined by the degree of their activity as a subject, features and opportunities to independently organize their actions, behavior, activities in general on the basis of intellectual readiness and awareness of personal and professional tasks, including professional tasks. Including the ones on a tactical level.

Keywords: model, professional training; law enforcement officers, Armed Forces of Ukraine, military institution of higher education.

УДК 355.235:37.091.2 (045)

DOI: https://doi.org/10.17721/1728-2217.2021.46.9-12

О. Бондаренко, заст. нач. Військ. ін-ту Київський національний університет імені Тараса Шевченка, Київ, Україна bondarenko1108@ukr.net ORCID ID 0000-0002-9991-6830

\section{ФОРМУВАННЯ ГОТОВНОСТІ МАЙБУТНІХ ОФІЦЕРІВ ЗБРОЙНИХ СИЛ УКРАЇНИ ДО ПРОФЕСІЙНОї ДІЯЛЬНОСТІ У ВІЙСЬКОВИХ ЛІЦЕЯХ ЯК ПЕДАГОГІЧНА ПРОБЛЕМА}

\begin{abstract}
Розглянуто готовність майбутніх офіцерів до професійної діяльності у військових ліцеях як теоретичну, так і практичну складову, оскільки лише в поєднанні з практикою можна правильно зорієнтуватися в освітньому процесі ВВНЗ та ВНП ЗВО під час виконання поставлених завдань щодо професійної підготовки офіцерів тактичного рівня та особливостей оцінки кінцевих результатів підготовки. Науково обґрунтовано мету і результат професійної підготовки. Оскільки головною метою будь-якого ВВНЗ є підготовка випускників до професійної діяльності, то головним орієнтиром і основою для розв'язання проблем формування готовності майбутніх офіцерів до професійної діяльності має стати сутність цієї діяльності, що відображає сукупність їі глибинних зв'язків, відношень і внутрішніх законів. Аналіз наукових праць надав підстави обґрунтувати авторське визначення готовності майбутніх офіцерів зСу до професійної діяльності у військовому ліцеї, яка передбачає формування цілісного особистісного утворення внаслідок спеціальної фахової та психолого-педагогічної професійної підготовки, що забезпечує перехід до якісно нової для курсанта форми життєдіяльності як майбутнього офіцера ЗСу й є сукупністю взаємозумовлених і взаємопов'язаних компонентів: мотиваційно-ціннісного, когнітивного та рефлексивного. Розглянуті критерії - важлива і визначальна ознака, яка характеризує різні якісні аспекти сутності та специфіку професійної діяльності військовослужбовця. Професійна діяльність офіцера ЗСу у військовому ліцеї вирізняється високим ступенем соціальної відповідальності, консервативності ціннісних орієнтацій, чіткою регламентацією умов її здійснення. У професійному середовищі військового ліцею значно зростає роль соціально зумовлених характеристик і умов діяльності як викладацького складу, до якого належать офіцери ЗСУ, так і учнів (ліцеїстів). Оволодіння професією офіцера ЗСУ - це не тільки здатність ефективно виконувати службові обов'язки, а й сприйняття відповідного способу життя, мислення, системи норм і цінностей.
\end{abstract}

Ключові слова: професійна готовність офіцера, освітній процес ВВНЗ та ВНП ЗВО, формування готовності майбутніх офіцерів до професійної діяльності, вихователь військового ліцею, педагогічна проблема.

Постановка проблеми. За сучасних умов загострення внутрішньої ситуації (проведення Операції об'єднаних сил) і зовнішньополітичного становища України, складних процесів реформування національної системи освіти, її інтегрування в європейський культурний простір актуалізується проблема підготовки офіцерів ЗСУ за світовими стандартами. Сьогодні, в умовах збереження зовнішньої воєнної загрози, в Україні предметом особли- вої уваги державного керівництва стає підготовка висококваліфрікованих захисників Батьківщини. Цей складний процес потребує тривалої, напруженої роботи з підготовки офріцерів ЗСУ до подальшого проходження служби у військових ліцеях і підготовки молоді до подальшого вибору військової спеціальності та навчання у вищих військових навчальних закладах.

Аналіз досліджень та публікацій. Проблема фрормування готовності до професійної діяльності отримала 
нове звучання в аспекті гуманістичної педагогіки, яка виникла в 60-80 роках XX ст. і пов'язана з іменами А. Маслоу [4], К. Роджерса [11] та ін. У психолого-педагогічній науці проаналізовано й обґрунтовано значення рушійних сил освітнього процесу під час фрормування готовності до опанування навчального матеріалу як психолого-педагогічної категорії (В. Крутецький [3] А. Кучерявий [16], В. Мерлін [5], О. Прохоров [9, 10], В. Ягупов [13, 14] та ін).

Значна кількість наукових досліджень присвячена питанню підготовки майбутніх офріцерів ЗСУ до професійної діяльності, серед них слід зазначити роботи М. Нещадима [6, 7], А. Зельницького [1], В. Рижикова [12, 15, 17], В. Ягупова $[13,14]$ та ін. Однак проблема формування готовності майбутніх офріцерів до проходження військової служби у військових ліцеях і до виконання там виховної робити в процесі професійної підготовки у вищих військових навчальних закладах тактичного рівня ще не знайшла достатнього осмислення й узагальнення в сучасній педагогіці.

Виклад основного матеріалу. Основною метою підготовки майбутніх офріцерів ЗСУ у вищих військових навчальних закладах тактичного рівня $є$ забезпечення цілісності освітнього процесу і власне підготовка кваліфікованого військового фахівця, здатного впродовж тривалого часу ефективно проваджувати професійну діяльність. На думку В. Ягупова та В. Свистун, основою формування готовності є системна багатогранна підготовка (психологічна, особистісна, теоретична, практична тощо) випускника ВВНЗ та ВНП ЗВО, який володіє відповідними своїй спеціальності професійними знаннями, навичками, вміннями та властивостями (тобто компетенціями) для здійснення професійної діяльності [13]. Зокрема, згадані науковці розробили відповідні показники професійної компетентності як основи готовності випускника до виконання своїх професійних обов'язків $[13,14]$, а саме:

- система знань, навичок та вмінь (сполучення фонових знань і професійного інтелекту з відповідною професійною та особистою підготовленістю для ефективної подальшої службової діяльності);

- професійна позиція фахівця (ставлення до реального стану справ і перспектив, самоорганізація повсякденної діяльності як частини роботи колективу);

- індивідуально-психічні особливості - в умовах виробничої або побутової діяльності, з урахуванням мети діяльності та її структури, спираючись на принципи суб'єктно-діяльнісного підходу формувати орієнтовну основу власних дій;

- акмеологічні інваріанти фахівця (стимули для самоосвіти і саморозвитку, що базуються на відомостях про особливості фрахової та повсякденної діяльності, прийоми саморегуляції та самоконтролю, творчого розвитку та розвитку командирських рис).

Готовність, як складне новоутворення особистості містить у собі не тільки когнітивний та операційний компоненти, а й мотиваційний, вольовий та аксіологічний складники, що забезпечує стійке прагнення до ефективного виконання діяльності. До того ж, усі складники готовності підпорядковуються тій діяльності, показником успішної реалізації якої і виступає готовність. Таким чином, готовність $€$ важливою умовою ефективної діяльності особистості $[16,17]$.

Можна зробити висновок, що поняття "готовність до професійної діяльності" у педагогіці має ширше поняття, ніж показник, тому стає можливим, коли для одного критерію готовності до професійної діяльності існує система показників. Під готовністю до професійної діяльності військовослужбовця В. Рижиков розуміє цілісний комплекс взаємопов'язаних елементів, сукупність взаємодіючих об'єктів і відносин [12]. Водночас, критерії і показники професійної готовності офріцерів ЗСУ до професійної діяльності тісно взаємопов'язані. Саму професійну готовність офріцера ЗСУ, як відзначає М. Нещадим, значною мірою зумовлює правильний вибір системи показників. У загальному вигляді показники, що характеризують ефективність профресійної готовності як діяльності окремого військового фахівця відносно оволодіння військовою спеціальністю, передбачають: ступінь сформованості інтелектуальних якостей (як результат залучення особистості до цілеспрямованої навчальної та наукової діяльності); ступінь сформованості морально-психологічних і ділових якостей (як результат залучення особистості у військово-педагогічній процес, соціалізації, самовдосконалення внаслідок створення відповідної мотиваційної основи) $[6,7]$.

Відповідно до словника С. Ожегова поняття готовність потрактовується як стан особистості, її інтерес, бажання, прагнення виконати ту чи іншу діяльність [8]. В. Крутецький визначає "готовність" як придатність до діяльності, що виражається в активному позитивному ставленні до неї, схильності займатися справою професійно. Поняття "готовність" охоплює також наявність певного запасу знань, навичок, умінь у відповідній царині [3]. Важливе місце в теорії професійної готовності належить В. Мерліну, який розкриває взаємозв'язок готовності до праці з проблемою розвитку особистості. Серед параметрів готовності до праці автор надає особливого значення особистісному параметру, розглядаючи готовність не лише як набір певних знань, навичок і вмінь, а як особистісну якість, детермінує діяльність [5]. Як зазначає А. Зельницький, професійна готовність офріцера ЗСУ ґрунтується на принципах структурної і змістової цілісності, діагностичної цілеспрямованості, логічної завершеності, вимірюваності, системності та керованості. Під метою розуміємо ідеальну модель бажаного результату під час формування особистості, до якого прагнуть у процесі спеціально організованої системи послідовної взаємодії як суб'єктів навчання, так і педагогів. Ступінь відповідності досягнутого результату цілям освіти як ідеальної моделі бажаного $є$ показником ефективності освітнього процесу $[1,2]$.

Профресійна діяльність офіцера ЗСУ у військовому ліцеї вирізняється високим ступенем соціальної відповідальності, консервативності ціннісних орієнтацій, чіткою регламентацією умов її здійснення. У професійному середовищі військового ліцею значно зростає роль соціально зумовлених характеристик і умов діяльності як викладацького складу, до якого належать офіцери ЗСУ, так і учнів (ліцеїстів). Із цього випливає, що освоєння професії офріцера ЗСУ - це не тільки здатність ефективно виконувати службові обов'язки, а й прийняття майбутнім офріцером відповідного способу життя, способу мислення, системи норм і цінностей.

У своєму дослідженні О. Прохоров стверджує, що педагогічна система впливає на процес формування готовності майбутніх офріцерів ЗСУ до професійної діяльності, тому що педагогічна система - це об'єднання компонентів (частин), яке залишається стійким під час змін. Якщо зміни (нововведення) перевищують якусь допустиму межу, система руйнується, на її місці виникає нова система $з$ іншими властивостями, що створює середовище для організації освітнього процесу і впливає в єдності на його якість та ефективність. В аспекті системного підходу, педагогічна система для якісної професійної підготовки має стійкий і водночас динамічний характер $[9,10]$.

Отже, зважаючи на вищезазначене і з урахуванням результатів проведеного аналізу наукових праць (М. Нещадим [6, 7], А. Зельницький [1, 2], О. Прохоров [10, 11], В. Рижиков $[12,15,17]$, В. Ягупов $[13,14])$, можемо надати власне визначення готовності майбутніх 
офіцерів ЗСУ до професійної діяльності у військових ліцеях. Готовність майбутнього офріцера ЗСУ до професійної діяльності у військових ліцеях - це результат професійної підготовки, що завершується цілісним особистісним утворенням, яке забезпечує перехід до якісно нової для курсанта форми життєдіяльності.

Отже, готовність майбутнього офріцера ЗСУ до професійної діяльності у військовому ліцеї передбачає формування цілісного особистісного утворення внаслідок спеціальної фахової та психолого-педагогічної професійної підготовки, що забезпечує перехід до якісно нової для курсанта форми життєдіяльності як майбутнього офріцера ЗСУ й є сукупністю взаємозумовлених і взаємопов'язаних компонентів: мотиваційно-ціннісного, когнітивного та рефлексивного.

Розглянемо докладніше зміст зазначених компонентів.

1. Мотиваційно-ціннісний компонент - це сукупність професійно зумовлених потреб, мотивів, система ставлень майбутнього офіцера ЗСУ до професійної діяльності, усвідомлення і прийняття професійних цінностей.

Мотиваційно-ціннісний компонент відображає:

а) мотивацію до педагогічної і виховної діяльності, що, на нашу думку, тісно пов'язано з проблемою вибору напряму специфіки діяльності військових підрозділів;

б) сформоване особистісне ставлення майбутнього офріцера до себе як до суб'єкта майбутньої професійної діяльності військового, а також усвідомлення змісту та необхідності виконання соціально значущих зобов'язань щодо забезпечення обороноздатності держави.

2. Когнітивний компонент - це знання й уявлення про зміст професії офіцера ЗСУ, вимоги до цієї професії, засоби розв'язання професійних завдань. Як було зазначено, професійна діяльність випускника військового вищого навчального закладу тактичного рівня $€$ складною i багаторівневою системою.

Когнітивний компонент охоплює сформовану готовність до навчання впродовж усього терміну проходження військової служби, що проявляється у:

а) здатності до самостійного оволодіння новими знаннями та сучасними інформаційними технологіями для пошуку інформації;

б) здатності швидко реагувати на зміни, що відбуваються в галузі професійної діяльності, власному стилі діяльності та критичності мислення;

в) прагненні професійного саморозвитку, самовдосконалення та самозбереження в ситуації швидкоплинності та швидкозмінюваності сучасного суспільства.

Таким чином, явищем, що відображає суть когнітивного компонента готовності майбутніх офріцерів ЗСУ до професійної діяльності у військовому ліцеї, буде сформований у курсанта образ професійної діяльності.

3. Рефлексивний компонент - це усвідомлення майбутнім офріцером себе суб'єктом професійної діяльності, самооцінка професійної підготовленості до служби у військовому ліцеї $[3,5]$.

Сформованість рефлексивного компонента готовності майбутнього офіцера ЗСУ до професійної діяльності у військовому ліцеї передбачає:

а) усвідомлення справжніх мотивів і суті діяльності (інтереси, створення умов для розвитку і саморозвитку, дотримання нормативних вимог тощо);

б) здатність адекватно оцінювати свою професійну діяльність 3 метою її коригування (співвідносити "Я - реальне", "Я - ідеальне" і "Я - потенційне" на основі потреби у самовдосконаленні).

Основною функцією рефлексивного компонента готовності $є$ забезпечення усвідомленого ставлення май- бутнього офріцера до профресійної діяльності, усвідомлення ним не тільки того, з чим він має справу, але й як він буде це робити або нести службу.

4. Професійно-особистісний компонент професійної діяльності офіцера-вихователя військового ліцею охоплює:

а) опанування курсантами ВВН3 - майбутніми офіцерами ЗСУ - сукупністю психолого-педагогічних знань, навичок, умінь (містить сукупність теоретичних знань, практичних навичок і умінь, досвіду в майбутнього військового командира, що сприяють пошуковій (евристичній) діяльності та науково-теоретичним розробкам);

б) оволодіння необхідними професійними знаннями та педагогічними навичками й уміннями, що визначає готовність до професійного удосконалення форм і методів виховного та викладацького складників у професійній діяльності офріцера, здатності систематично працювати над поглибленням знань, активізувати пізнавальну діяльність з метою формування теоретико-пізнавальної спрямованості професійної спеціалізації у підлеглих;

в) інструментальні вміння, що забезпечують здатність аналізувати, синтезувати, порівнювати, систематизувати, узагальнювати, генерувати ідеї, набувати знання, використовуючи вміння знаходити й опрацьовувати інфоомацію з різних джерел, володіння інформаційними засобами та технологіями, рідною та іноземною мовами;

г) прогнозувати, програмувати, планувати, організовувати та контролювати різні види робіт, зокрема: навчально-виховну діяльність у підлеглому військовому підрозділі, керувати собою, що передбачає самовладання людини, яке проявляється у критичних ситуаціях, чи професійна гнучкість, що характеризується вмінням запобігати конфліктам і знаходити оптимальні шляхи їхнього розв'язання.

Професійно-особистісний компонент відображає такі якості особистості майбутніх офріцерів ЗСУ, які характеризують офріцера не тільки як фахівця певної військової спеціальності, а й як розвинену особистість, якій притаманні сорормовані особистісні цінності, що реалізуються в безпосередній професійній діяльності та в контексті педагогічної діяльності як майбутнього вихователя і вчителя для підлеглого особового складу.

Висновки. Оскільки готовність майбутнього офріцера до професійної діяльності розуміють як складне особистісне утворення, що має властивості системи, то слід зазначити, що всі вищеназвані компоненти готовності тісно взаємопов'язані та взаємозумовлені. Виходячи із цього, формування професійної готовності майбутніх офріцерів до проходження служби у військових ліцеях недоцільно та неможливо здійснювати окремо, "частинами". Це необхідно враховувати під час визначення сукупності педагогічних умов, форм і методів, спрямованих на формування готовності майбутнього офріцера до професійної діяльності.

Ураховуючи вищевикладене, можемо зробити висновок, що готовність офіцера тактичного рівня підготовки до професійної діяльності у військовому ліцеї забезпечується сфрормованістю сукупності компонентів (мотиваційно-ціннісного, професійно-педагогічного, професійноособистісного) та відповідних їм показників, що в сукупності відображає і готовність офріцерів до навчально-виховної діяльності серед підлеглих, і сформованість їхньої готовності до професійно-педагогічної діяльності на посаді офріцерів-вихователів військового ліцею.

Перспективи подальшого дослідження. Формування готовності має забезпечити перехід до нового типу інноваційної військової освіти, що сприятиме зростанню військово-професійного, інтелектуального, культурного, духовно-морального потенціалу офіцерів ЗСУ 
до подальшої плідної служби у військових ліцеях і підготовки молодого покоління юнаків до військової служби. Успішна підготовка до інноваційної військової освіти може бути реалізована за певних педагогічних умов.

Список використаної літератури

1. Зельницький А. М. Якість вищої військової освіти як результат функціонування педагогічної системи ВВНЗ : зб. наук. пр. // Військова освіта. Нац. ун-ту оборони України імені Івана Черняховського, 2017. № 1 (35). С. 62-69.

2. Зельницький А. М. Концептуальні засади гарантування якості підготовки майбутніх офріцерів Збройних Сил України у вищих військових навчальних закладах // Вісн. Черкаськ. ун-ту. Педагогічні науки, 2017. № 6. C. $71-83$.

3. Крутецкий В. А. Основы педагогической психологии. Москва : Просвещение, 1972. 255 с.

4. Маслоу Абрахам Х. Мотивация и личность. СПб : изд-во "Питер", 2011. 352 c.

5. Мерлин В. С. Очерк интегрального исследования индивидуальности. Москва : Педагогика, 1986. 253 с.

6. Нещадим М. І. Військова освіта в Україні: історія, теорія, методологія,

7. Нещадим М. І. Деякі методологічні проблеми розробки універсальної моделі військового фахівця: зб. наук. пр. ВГІ НАОУ, 2000. Вип. 1 (14). С. 3-10.

8. Ожегов С. И. Словарь русского языка / под ред. Н. Ю. Шведова. Москва : Рус. язык, 1988. 748 с.

9. Прохоров О. А. Формування готовності майбутніх осріцерів до професійної діяльності на засадах педагогічного менеджменту : дис. ... канд. пед. наук : 13.00.04. Київ, 2011. 308 арк. С. 280-308.

10. Прохоров О. А., В. С. Рижиков. Інтерактивні методи навчання: теорія та практика впровадження ділових (рольових) ігор в освітній процес військових навчальних закладів // Інноваційна педагогіка, Одеса, 2020. Вип. № 21. Т. 3. С. 87-92.

11. Роджерс К. Р. Становление личности. Взгляд на психотерапию/ пер. с англ. М. Злотник. Москва : изд-во ЭКСМО-Пресс, 2001. 416 с.

12. Рижиков В. С. Теорія і практика конструювання цільових моделей (професіограм) та процесу професійної підготовки майбутніх юристів : монографрія. Херсон, ТОВ "Айлант", 2012. 280 с.

13. Ягупов В. В., Свистун В.І.Компетентнісний підхід до підготовки фахівців у системі вищої освіти // Наук. записи НаУКМА. Серія: Педагогічні, психологічні науки та соціальна робота, 2007. Т. 71. С. 3-8

14. Ягупов В. В. Військова дидактика : навч. посіб. Київ : ВПЦ "Київський університет", 2000. 400

15. Horiacheva K., Ryzhykov V. The oreticales sence and practice of implementation of the system approach in formation of professional reliability of future officersin the armed forces of Ukraine // Вiсн. Київ. нац. ун-ту імен Тараса Шевченка. Військово-спеціальні науки, 2019. № 2 (42), С. 57-60.

16. Kucheriavyi A. O., Atamanchuk Yu. M., Yablonskyi A. I. Teaching the Future Military Psychologists by Immersing them into a Pedagogical Situation [Електронний ресурс] // International Journal of Innovative Technology and Exploring Engineering (IJITEE), 2019. Vol. 9, Issue 2 (Dec. 2019). pp. 48-53. URL :https://www.ijitee.org/wp-content/uploads/papers/ v9i2/A4798119119.pd.

17. Ryzhykov V. Bakhov I., Kolisnyk O. Leadership Abilities of a Military Manager, Professionalism of a Commander as the Guarantee of the Practice of Effective Activity of a Military Organization // Internat. Jour. of Engineering \& Technology, 2018. Vol 7, No 4.38. Special Issue 38. C. 45-49.

\section{References}

1. Zelnytskyi, A. (2017). The quality of higher military education as a result of the functioning of the pedagogical system of higher military educational institutions. Collection of scientific works "Military Education" of the National University of Defense of Ukraine named after Ivan Chernyakhovsky. 1 (35), 62-69 [In Ukrainian].

2. Zelnytskyi, A. (2017). Conceptual principles of guaranteeing the quality of training of future officers of the Armed Forces of Ukraine in higher military educational institutions. Bulletin of Cherkasy University. Pedagogical sciences, 6, 71-83 [In Ukrainian].

3. Krutetskii, V. (1972). Fundamentals of pedagogical psychology. Moscow: Enlightenment. [In Russia]

4. Maslou, A. (2011). Motivation and personality. St. Petersburg: Publishing house "Piter". [In Russia].

5. Merlyn, V. (1986). Outline of the integrated research of individuality. Moscow: Pedagogy. [In Russia]

6. Neshchadym, M. (2003). Military education in Ukraine: history, theory, methodology, practice: monograph. Kyiv: Kyiv University Publishing and Printing Center. [In Ukrainian].

7. Neshchadym, M. (2000). Some methodological problems of developing a universal model of a military specialist. Collection of scientific works of National Defense Academy of Ukraine, 1 (14), 3-10. [In Ukrainian].

8. Ozhegov, S. (1988). Dictionary of the Russian language / ed. N. Yu. Shvedova. Moscow: Russian language. [In Russia]

9. Prokhorov, O. (2011). Formation of readiness of future officers for professional activity on the basis of pedagogical management: published thesis (PhD in Pedagogical Science). [In Ukrainian]

10. Prokhorov, O.\& Ryzhykov, V. (2020). Interactive teaching methods: theory and practice of introduction of business (role) games in the educational process of military educational institutions. Innovative pedagogy: scientific journal, Issue № 21 volume 3. [In Ukrainian].

11. Rodzhers, K. (2001). Formation of personality. A look at psychotherapy. Moskow, EKSMO-Press Publishing House [In Russia].

12. Ryzhykov, V. (2012). Theory and practice of designing target models (professiograms) and the process of professional training of future lawyers: monograph. Kherson, Ailant Limited Liability Company. [In Ukrainian].

13. Yahupov, V. \& Svystun, V. (2007). Competence approach to training specialists in the higher education system. Scientific records National University "Kyiv-Mohyla Academy". Series "Pedagogical, psychological sciences and social work". Volume 71, PP. 3-8. [In Ukrainian].

14. Yahupov, V. (2000). Military didactics: a textbook. Kyiv: Kyiv University. [In Ukrainian].

15. Horiacheva, K. \& Ryzhykov, V. (2019). The oreticales sence and practice of implementation of the system approach in formation of professional reliability of future officersin the armed forces of Ukraine. Bulletin of Taras Shevchenko National University of Kyiv. Military special sciences. 2 (42). [In Ukrainian].

16. Kucheriavyi, A. etc. (2019) Teaching the Future Military Psychologists by Immersing them into a Pedagogical Situation. International Journal of Innovative Technology and Exploring Engineering (IJITEE). 2019. Volume 9, Issue 2 (December 2019). pp. 48-53. URL: https://www.ijitee.org/ wp-content/uploads/papers/v9i2/A4798119119.pd.

17. Ryzhykov, V. etc. (2018). Leadership Abilities of a Military Manager, Professionalism of a Commander as the Guarantee of the Practice of Effective Activity of a Military Organization. International Journal of Engineering \& Technology; Vol 7, No 4.38 (2018): Special Issue 38, 45-49.

Надійшла до редколегії 23.02.21

O. Bondarenko, Deputy Head of the Military Institute Taras Shevchenko National University of Kyiv, Kyiv, Ukraine bondarenk01108@ukr.net ORCID ID 0000-0002-9991-6830

\section{TRAINING OF FUTURE OFFICERS OF THE ARMED FORCES OF UKRAINE FOR PROFESSIONAL ACTIVITY IN MILITARY LYCEUMS AS A PEDAGOGICAL PROBLEM}

In the scientific article the training of future officers for professional activity in military lyceums is considered as not only theoretical but also practical component, because without the theoretical component in combination with practice it is impossible to orient properly in the educational process of higher military educational institutions and military training units of higher educational institutions during the training of tactical level officers and the assessment of training final results. The training of future officer of the Armed Forces of Ukraine for professional activity in military lyceum is considered and scientifically substantiated both as a purpose and as a result of professional training. Since the main purpose of any higher military educational institution is to prepare the graduates for professional activity, the main guideline and basis for solving the problems of training of future officers for professional activity should undoubtedly be the essence of this activity, which reflects the set of its deep connections, relations and internal laws. The detailed analysis of the scientific works provided grounds to substantiate the author's determination of training of future officers of the Armed Forces for professional activity in military lyceum, which provides the formation of a holistic personal education as a result of special professional and psychological-pedagogical professional training, which ensures the transition to a qualitatively new form of activity for the cadet as a future officer of the Armed Forces and it is a set of interdependent and interconnected components: motivational-value, cognitive and reflexive. The criterias of readiness for professional activity of an officer of the Armed Forces of Ukraine as an important and defining feature that characterizes various qualitative aspects, essences and specifics of professional activity of a serviceman are evaluated. The professional activity of an officer of the Armed Forces of Ukraine in a military lyceum is characterized by a high degree of social responsibility, conservatism of values and clear regulation of the conditions for its implementation. In the professional environment of the military lyceum, the role of socially conditioned characteristics and conditions of activity of both faculty that includes officers of the Armed Forces, and pupils (lyceum students) is significantly increasing. It follows that mastering the profession of an officer of the Armed Forces is not only the ability to effectively perform duties, but also the adoption of the appropriate lifestyle, way of thinking, system of norms and values by a future officer.

Keywords: professional readiness of an officer, educational process of higher military educational institution and military educational department of higher educational institution, formation of readiness of future officers for professional activity, educator of a military lyceum, pedagogical problem. 